\title{
Original article \\ DETERMINANTS OF HEPATOCELLULAR CARCINOMA IN CLINICAL ONCOLOGY AND NUCLEAR MEDICINE DEPARTMENT IN ZAGAZIG UNIVERSITY HOSPITALS: A RETROSPECTIVE ANALYSIS OF 538 CASES \\ Nahla Mokhtar Abdelmawla, Yousra Taha Dorgham, Eman Ismail Ibrahim, Lobna Abdelaziz Abdelaziz. \\ Clinical Oncology \& Nuclear Medicine Department, Faculty of Medicine, Zagazig University, Zagazig,
} Egypt

Corresponding author:

Nahla Mokhtar Abdelmawla Morsi

Clinical Oncology \& Nuclear Medicine Department, Faculty of Medicine, Zagazig University, Zagazig, Egypt Nahla_mokhtar@yahoo.com

$\begin{array}{ll}\text { Submit Date } & 2019-02-10 \\ \text { Revise Date } & 2019-02-19 \\ \text { Accept Date } & 2019-02-17\end{array}$

\section{INTRODUCTION}

$\mathrm{CC}$ is the fifth most common cancer in the world and the third cause of cancer mortality ${ }^{(1),(2)}$. There were nearly 782000 HCC diagnosed cases all over the world in 2012; most of cases were diagnosed in developing countries ${ }^{(3)}$. There is a difference in the age around which HCC is diagnosed which depends on sex, residence, and exposure to certain risk factors leading to cancer development. At the age of sixty, the most common cause of HCC development is chronic liver diseases (CLD) including chronic infection by hepatitis $\mathrm{C}$ virus (HCV) and Hepatitis B virus (HBV) .Moreover, congenital liver disorders are the most common causes of HCC in children and adolescents, generally females are diagnosed at age older than that of males ${ }^{(4)}$.HCC in Egypt is linked to $\mathrm{HCV}$ related cirrhosis more than non-viral causes of CLD, Egypt has the highest infection by HCV

\section{ABSTRACT}

Background: Hepatocellular carcinoma (HCC) is one of the most common malignant tumors in the world and it's prevalence in Egypt has been rising in the last few years. The aim was to study determinants of HCC in Clinical Oncology and Nuclear Medicine Department in Zagazig University Hospitals.

Methods: This is a retrospective chart review of 538 patients with HCC conducted from 2012 to 2017. Analysis of data in files was done to study the determinants of HCC. detected in only $(3.10 \%)$ of cases.

Conclusion: HCC is a major health problem in Zagazig and its incidence is early detection of mild HCCs cases.

Keywords: HCC, Cirrhosis, HCV and HBV.

in the world (genotype 4 is the most common type), which has been caused by public health plans for treatment of patients infected by schistosomiasis ${ }^{(5)}$.

To study the determinants of HCC in Zagazig, we comprehensively analyzed patients with HCC from 2012 to 2017 with regard to their age, sex, residence, laboratory and radiological profile.

\section{PATIENTS AND METHODS}

This is a retrospective chart review of $\mathrm{HCC}$ patients done in the period from January 2012 to December 2017 for those who attended Clinical Oncology and Nuclear Medicine department in Zagazig University Hospitals.

Minimum data set within the patient record was predefined before collection of data to include a record in this retrospective study. $\mathrm{HCC}$ cases in Clinical Oncology and Nuclear Medicine in Zagazig University Hospitals were diagnosed according to American Association for the 
Study of Liver Diseases (AASLD) practice guidelines ${ }^{(6)}$.

Written informed consent was obtained from all participants and the study was approved by the research ethical committee of Faculty of Medicine, Zagazig University.

\section{STATISTICAL METHODS}

Data analysis was performed using IBM SPSS statistics. Mean and Standard Deviation were used for quantitative parametric measures, Median Percentiles for nonparametric ones and both number and percentage for categorized data.

\section{RESULTS}

The demographical data of HCC cases was presented in table 1. As for age, it was observed that most of cases were in their 50s (40\%), male to female ratio was 3:1 and nearly $72.1 \%$ of cases were from urban areas.

As regard to laboratory ( $\mathrm{HCV}, \mathrm{HBV})$ and radiological data (cirrhosis) of studied patients. It was noticed that in the majority of cases (89.96\%), HCV was positive while only $3.15 \%$ of patients had positive HBV results. About $99.07 \%$ of patients had cirrhotic liver as detailed in table2.

Table1. Demographic data of HCC patients in Zagazig

\begin{tabular}{|l|c|c|}
\hline & & \\
\hline $\begin{array}{l}\text { Age } \pm \text { SD } \\
\text { Median }\end{array}$ & $60.2 \pm 8.9$ & \\
\hline Age category & 60.0 & \\
\hline $\mathbf{2 1 - 3 0}$ & 2 & $0.37 \%$ \\
\hline $\mathbf{3 1 - 4 0}$ & 9 & $1.67 \%$ \\
\hline $\mathbf{4 1 - 5 0}$ & 62 & $11.5 \%$ \\
\hline $\mathbf{5 1 - 6 0}$ & 216 & $40 \%$ \\
\hline $\mathbf{6 1 - 7 0}$ & 188 & $34.9 \%$ \\
\hline $\mathbf{7 1 - 8 0}$ & 57 & $10.6 \%$ \\
\hline $\mathbf{8 1 - 9 0}$ & 4 & $0.74 \%$ \\
\hline Sex & & $77 \%$ \\
\hline Males & 416 & $23 \%$ \\
\hline Females & 122 & $72.1 \%$ \\
\hline Residence & & $27.8 \%$ \\
\hline Urban & 388 & \\
\hline Rural & 150 & \\
\hline
\end{tabular}


Table2. Viral markers and radiological (cirrhotic) data of the studied patients

\begin{tabular}{|l|c|c|}
\hline & \multicolumn{2}{|c|}{} \\
\hline Viral markers & & $\%$ \\
\hline HCV+ & 484 & $89.96 \%$ \\
\hline HCV- & 29 & $5.39 \%$ \\
\hline HBV+ & 17 & $3.15 \%$ \\
\hline HBV- & 108 & $20.07 \%$ \\
\hline HCV+/HBV+ & 13 & $2.41 \%$ \\
\hline HCV-/HBV+ & 4 & $0.74 \%$ \\
\hline HCV-/HBV- & 8 & $1.48 \%$ \\
\hline HCV+/HBV- & 100 & $18.59 \%$ \\
\hline Cirrhotic liver & 533 & $99.07 \%$ \\
\hline Non cirrhotic liver & 5 & $0.93 \%$ \\
\hline
\end{tabular}

\section{DISCUSSION}

$\mathrm{HCC}$ is the most common primary liver malignancy. Incidence is rising and HCC has increased to become the fifth most common type of cancer in the world and the 3rd leading cause of cancer mortality ${ }^{(7)}$. There is wide spreading of HCC all over the world including both developed and less developed countries like Egypt which is related to $\mathrm{HCV}$ transmission by the reuse of needles for injection of tartar emetic to get rid of schistosomiasis back in 1950 and until thirty years after ${ }^{(8)}$.

HCC was observed in nearly $4.7 \%$ of chronic liver disease cases in Egypt ${ }^{(9)}$.

In 2005, El-Zayadi et al., noticed a very high rise in the percentage of HCC among chronic liver disease patients (from $4 \%$ to $7.2 \%$ ) in more than a decade ${ }^{(10)}$.

This rise may be related to the increase of risk factors such as hepatitis $\mathrm{C}$ and $\mathrm{B}$ virus infection as well as the improvement of the screening programs and methods of diagnosis (11)

The current work was done to study the determinants of HCC in clinical oncology and nuclear medicine in Zagazig University Hospitals patients with HCC.

In this study, age of HCC cases was $60.2 \pm$ 8.9 years with a median age of 60 years. The highest rates were noticed at ages between 51 and 70 years (50s then 60s). Similarly, 56 years old was the median age of Egyptian HCC cases according to Mohamed et al., also 52 years old was the median age of $\mathrm{HCC}$ cases included in a study conducted by Kumar et al. ${ }^{(12),}$ (13). According to Bosch, HCC development probability rises with age (14). HCC is not common before 40s in western people. Most of $\mathrm{HCC}$ cases according to some Indian studies were in $60 \mathrm{~s}$ and $70 \mathrm{~s}$ as and this is compatible with this study ${ }^{(15)}$.

Percentage of males in all age groups was higher than females in most populations with an average male to female proportions between $2: 1$ and $4: 1^{(16)}$.

In the present study, 3:1 was the male to female ratio which is compatible with most records. Exposure of men in some areas to certain risk factors makes them more susceptible than women to HCC development.

For example, men working as farmers in rural areas in Egypt were more susceptible to be infected by $\mathrm{HCV}$ during eradication of bilharziasis which is a major risk factor for development of liver cirrhosis and $\mathrm{HCC}^{(8)}$. In this study, majority of patients $(72.1 \%)$ were from urban areas and only $27.8 \%$ of patients were from rural areas as population from urban areas seek medical advice and more concerned with health issues and may be also related to that patients tend to tell the nearest urban areas instead of their real rural residence.

In this study, $89.96 \%$ of patients were infected by $\mathrm{HCV}, 3.15 \%$ by $\mathrm{HBV}, 2.41 \%$ by both HBV and HCV together and $1.48 \%$ of patients were free of viral infection. Mohamed et al. noticed in their study that HCV has a high prevalence as $\mathrm{HCV}$ was presented in $64.4 \%$ 
and HBV was in only $17.5 \%$ while combined infection was detected in $11.2 \%^{(12)}$.

High prevalence of $\mathrm{HCV}$ was the main cause for increasing HCC prevalence (17). Nearly $14 \%$ of Egyptian people were infected by $\mathrm{HCV}{ }^{(18)}$. HCV causes HCC through both cirrhosis and viral mutagenic effect on hepatocytes ${ }^{(19)}$. In this study $89.96 \%$ of patients were infected by $\mathrm{HCV}$.

According to El-Zayadi et al. study which was applied from the beginning of 1993 to the end of 2002, 86.9\% of HCC Egyptian patients were infected by HCV and $28.4 \%$ of them were infected by HBV, they also observed that there was a decrease in HBV proportion, increase in $\mathrm{HCV}$ proportion and decrease in proportion of both HCV and HBV together. They clarified that HBV infection decreased due to good measures taken in consideration for safe blood transfusion applied within the mid-1970s and somewhat due to the development of $\mathrm{HBV}$ infection with some sort of mutation, which needs high costly diagnostic tests ${ }^{(10)}$. In this study HCV related HCC incidence rate is much higher than that of HBV this may be related to HBV immunization programs. In this study, viral markers were -ve in $1.5 \%$ of cases. About $14.5 \%$ of HCC cases who were included in ElSerag study having non cirrhotic liver and without specific risk factors ${ }^{(17) .}$ This could be due to exposure to risk factors like aflatoxins, excess alcohol intake or DM. Bilharziasis is still acting a great role in HCC development (20). In Egypt, Bilharziasis is a major health problem and infection with Schistosoma mansoni acts the major role in development of liver disease. In the period between 1950 to 1980, public health programs for getting rid of bilharziasis by injection of tartar emetic using contaminated needles led to wide spread of $\mathrm{HCV}$ infection predominantly genotype $4^{(21)}$. There is a proof that bilharziasis and hepatitis $\mathrm{C}$ virus infection together can cause more serious complications like development of early portal hypertension with rapid progression to fibrosis and liver cancer, this occurs quicker than in cases that do not have a bilharzial parasite infection ${ }^{(5)}$.

\section{CONCLUSION}

It is concluded that hepatocellular carcinoma is a major health problem in Zagazig and its incidence is increasing. The high prevalence of HCV infection makes screening programs, and the surveillance of those patients represents a very important tool for early detection of small HCCs cases. Further studies focusing on risk factors other than viral infections are warranted.

\section{Declaration of interest}

The authors report no conflicts of interest. The authors alone are responsible for the content and writing of the paper.

\section{Funding information}

None declared

\section{REFERENCES}

1. Parkin DM, Ferlay J, Hamdi-Cherif $M$ et al. (1999): " Estimates of the worldwide incidence of 25 major cancers". Int J Cancer, 80: 827-841.

2. Kew MC (2012): "Hepatocellular carcinoma in sub-Saharan Africa". Trafford Publishing (North America and International), 9.

3. Jorge A. Marrero, Laura M. Kulik, Claude B. Sirlin et al. (2018): " Diagnosis, Staging, and Management of Hepatocellular Carcinoma: 2018 Practice Guidance by the American Association for the Study of Liver Diseases". Hepatology, 68, 2.

4. Bosch FX, Ribes J, Diaz M, et al., (2004). "Primary liver cancer: worldwide incidence and trends". Gastroenterology 127:S5-S16.

5. Hassan MM, Zaghloul AS, El-Serag HB, et al. (2001). "The role of hepatitis $C$ in hepatocellular carcinoma: a case control study among Egyptian patients". J Clin Gastroenterol 33: 123-6.

6. Bruix J, Sherman M (2011). "American Association for the Study of Liver Diseases. Management of hepatocellular carcinoma: an update". Hepatology, 53, 1020- 2.

7. World Health Organization. Mortality database. Available at http://www.who.int /whosis/en.

8. Frank C, Mohamed MK, Strickland GT, et al (2000). "The role of parenteral antischistosomal therapy in the spread of hepatitis $\mathrm{C}$ virus in Egypt". The Lancet 355: 887-91.

9. El-Zayadi AR, Abaza H, Shawky $S$ et al (2001). "Prevalence and epidemiological features of hepatocellular carcinoma in Egypt-a single center experience". Hepatol Res 19: 1709.

10. El-Zayadi AR, Badran HM, Barakat EM, et al (2005). "Hepatocellular carcinoma in Egypt: a 
single center study over a decade". World J Gastroenterol 11: 5193-8.

11. El-Serag HB (2001). " Epidemiology of hepatocellular carcinoma". Clin Liver Dis 5: 87-107.

12. Mohamed N, Elzawahry H, Mokbtar $\mathrm{N}$ et al. (2000). "Review of epidemiologic and clinicopathologic features of 403 hepatocellular carcinoma patients". Natl J Cancer Inst 12: 8793.

13. Kumar R, Saraswat MK, Sharma BC et al. (2008). "Characteristics of hepatocellular carcinoma in India: a retrospective analysis of 191 cases". QJM 101: 479-85.

14. Bosch FX (1997). "Global epidemiology of hepatocellular carcinoma. In: Okuda K, Tabor E, eds. Liver Cancer". New York: Churchill Livingstone 13-27.

15. Pyrsopoulos N, Reddy RK (2002). "Hepatocellular carcinoma in Asia. In: Sarin SK, Okuda K, eds. Hepatitis B and C. Carrier to Cancer". India: Elsevier Sciences 363-4.
16. Nordenstedt H, White D, El-Serag $H$ (2010). "The changing pattern of epidemiology in hepatocellular carcinoma". Dig Liver Dis 42 (3): S206-14.

17. El-Serag HB (2002). "Hepatocellular carcinoma: an epidemiologic view". J Clin Gastroenterol 35 (2): S72-8.

18. Heintges T, Wands JR (1997). "Hepatitis C virus: epidemiology and transmission". Hepatology 26: 521-6.

19. El-Nady GM, Ling R, Harrison TJ (2003). "Gene expression in HCV associated hepatocellular carcinoma-up regulation of a gene encoding a protein related to the ubiquitinconjugating enzyme". Liver 23: 2935.

20. El-Zayadi AR (2004). "Curse of schistosomiasis on Egyptian liver". World J Gastroenterol 10: 1079-81.

21. Strickland GT (2006). "Liver disease in Egypt: hepatitis C superseded schistosomiasis as a result of iatrogenic and biological factors". Hepatology 43: 915-22.

To cite this article: Abdelmawla NM, Dorgham YT, I Ibrahim El, Abdelaziz LA.. Determinants of hepatocellular carcinoma in clinical oncology and nuclear medicine department in zagazig university hospitals: a retrospective analysis of 538 cases.Egypt.ZUMJ 2019;25(3);396-400,DOI: 10.21608/zumj.2019.8145.1052 